\title{
Foxes and Lions: How Institutional Leaders Keep Organisational Integrity and Introduce Change
}

\author{
Marta Struminska-Kutra and Harald Askeland
}

\section{Introduction}

Theoretical considerations presented in this chapter develop empirical findings from multiple case studies of Polish public administration entities struggling to adapt to field-level changes in governance patterns (Bevir, 2011; Gilardi \& Radaelli, 2012; Strumińska-Kutra, 2018), particularly to environmental pressures for more inclusive and participatory public management. With the emergence of these pressures, public agencies in many Western and Central-Eastern European (CEE) countries have begun to function within institutional pluralism-between the traditional, hierarchically oriented paradigm of public administration (PA), the market-oriented paradigm of New Public Management (NPM), and the network-oriented paradigm of New Public Governance

\footnotetext{
$\overline{\text { M. Struminska-Kutra }(\bowtie)} \cdot$ H. Askeland

VID Specialized University, Oslo, Norway

e-mail: marta.struminska@vid.no

H. Askeland

e-mail: harald.askeland@vid.no 
(NPG) (Kordasiewicz \& Sadura, 2017). Each of these paradigms prioritises different logics, promotes different values and delivers a different frame for their interpretation. Consequently, each provides a different way of conceptualising the public administration's identity and role in society. Hence, in order to keep legitimacy, public agencies must learn to perform accordingly.

We adopt the institutional leadership perspective by asking: How leaders build organisational structures that embody new goals and values while at the same time keeping organisational integrity? While changing their own organisations, how do they gain cooperation from internal and external constituencies and reconcile otherwise conflicting tendencies? We review public administration leaders' interactions with internal and external constituencies to show how leaders choose different strategies of adaptation. Some act as 'foxes', working to associate new rules and practices with old ones. Others represent 'lions', whose goal is to secure the survival of innovations and prevent them from drift or co-optation. This typology of leaders-innovators, briefly mentioned by Selznick, represents indispensable features of institutional leadership that combine cohesive force for change with an understanding that winning consent for new directions depends on how secure the participants feel (Selznick, 1957, p. 153). We explore these two types and supplement them with two others. The strategy of an 'ostrich' responds to environmental pressures for change by faking innovation, or using new rhetoric while in fact resorting to routine. A 'mole' does not even notice new qualities of the situation and reinterprets new expectations in the old, routinised frames. Normatively speaking, the latter two types escape from the true functions of leadership that are about defining (new) ends in the face of ambiguity and pluralism, designing an enterprise adapted to these ends, and ensuring that the design becomes a living reality (Selznick, 1957, p. 37).

We contribute to the literature on institutional leadership in two ways. First, we complement a dominant focus on the backward-leaning orientation of institutional leaders (Washington, Boal, \& Davis, 2008) by exploring their future-oriented, innovative side. Using the concept of institutional work; purposive action aimed at creating, maintaining and disrupting institutions (Lawrence \& Suddaby, 2006), we illustrate how leaders intentionally work to change organisations and their values. 
We argue that their actions manifest either through projective, futureoriented agency or through habitual agency by selecting among a set of established routines. Reference to projective and habitual agency constitutes our second contribution, emphasising that institutional leaders act in an arena that is never empty of institutions. In particular, the leader herself is an institutionally embedded individual whose patterns of thinking and acting are conditioned by field-level and organisational institutions. In this messy environment, leaders struggle to build structures that reflect new goals and internalise different or even conflicting values, as well as even deinstitutionalise some. Our typology explicates ways in which leaders respond to these challenges.

Consistent with the aim of this book, we explore how values come into play in situations of institutional pluralism. ${ }^{1}$ Our argument is developed in two sections. First, we present Selznick's concept of institutional leadership. Then, we link neo-institutional approaches, nested in the fieldlevel perspective (isomorphism), with the micro-level perspective (institutional work). We present leaders as those who perform the institutional work of translating (plural) field-level logics into organisational structures, as well as those who negotiate the shape of organisational structures with actors both inside and outside of the organisation. The second section presents the typology of leaders/innovators responding to environmental pressures for change by reaching to old and new institutional scripts. We conclude by comparing the strategies and reflect on their effectiveness within the context of institutional pluralism.

\section{Institutional Leadership: Linking Field, Organisation and Actor Levels}

The idea of institutional leadership-the promotion and protection of values (Selznick, 1957, p. 28) — does not appear often in contemporary theoretical discussions (Kraatz, 2009; Kraatz \& Block, 2017). When it does, it tends to be perceived as conservative and backward leaning

\footnotetext{
${ }^{1}$ Such contexts are outlined in the introductory chapter (Askeland, Espedal, Løvaas and Sirris) and elaborated on in the chapter of Sirris on institutional complexity.
} 
(Washington et al., 2008). Yet, a forward-looking orientation was prominent in the original concept. According to Selznick (1957), institutional leaders respond to diverse external pressures by making critical decisions that affect the basic character of an enterprise, and these critical decisions go beyond the routine, day-to-day solution of problems. They are about navigating 'uncharted waters', making structural changes that, on the one hand, enable the pursuit of new goals and values and, on the other, recognise the status quo and its limitations. Institutional leadership is about decisions having long-running implications for organisational identity and organisation's role and meaning in wider societal networks. These decisions create conditions 'that will make possible in the future what is excluded in the present' (Selznick, 1957, p. 154). Selznick (1957) argued that such adaptations to new goals 'require a strategy of change that looks to the attainment of new capabilities more nearly fulfilling the truly felt needs and aspirations of the institution' (p. 154).

Selznick located institutional leaders in a 'liquid' and turbulent reality, where it is not (or no longer) clear for an organisation what it should be or what it should do. In such circumstances, there are four functions of institutional leadership: (1) defining values, mission and role entails an assessment of the organisational commitments set by internal and external demands; (2) building structures creates new organisational arrangements that are sensitive to the existing ones, as well as to ways of thinking and responding that secure the execution and elaboration of the new policy; (3) defending integrity means maintaining values and distinctive identity; (4) ordering internal conflicts means winning the consent of constituent units in order to maximise voluntary cooperation while keeping the balance of power to maintain the fulfilment of key commitments (Selznick, 1957, pp. 62-63).

Contemporary accounts of institutional leadership have developed some aspects of this list. Washington et al. (2008) shifted emphasis from the internal to external orientation of leaders, claiming that the leader's function is to develop external supporting mechanisms, thereby enhancing the legitimacy of an organisation, and to overcome external enemies. While viewing institutional leaders' actions as institutional work, Kraatz (2009) supplemented the list with an individual dimension of self-reflection. He suggested that some leaders should also work 
on themselves and undergo transformations when experiencing 'complex and anxiety laden social situations' (p. 81). Others have reflected on integrative function while referring to the frame of institutional logics, pluralism, complexity, and organisational hybridity (Besharov \& Khurana, 2015; Kraatz \& Block, 2017). They called for empirically grounded perspectives on how leaders develop both an organisational and individual identity that integrate potentially diverse goals and moralities, as well as how they foster productive rather than destructive tensions between potentially conflicting views of who the organisation is and should be. We will enhance this perspective by investigating institutional and organisational changes in public administration.

\section{Institutional Pluralism and Public Administration}

Selznick's contemporary relevance increases when we consider his references to pluralism in an organisation and its environment. Such pluralism is exhibited in various expectations about organisational roles and identity, comes from diverse organisational stakeholders and foreshadows concepts of institutional pluralism and institutional logics (Gawer \& Phillips, 2013; Thornton, Ocasio, \& Lounsbury, 2012). Institutional pluralism is the situation faced by an organisation that operates in multiple institutional spheres. Organisations become multiply constituted when they have more than one socially sanctioned purpose (Kraatz \& Block, 2017). Pluralism creates internal tensions, shifts objectives and turns administrators into institutional leaders-political players whose actions and choices ultimately shape the organisation's evolution and character. Hence, institutional leadership, when focusing on organisations, becomes a concept of 'gluing' field-level considerations with an individual-level analysis of practices, aiming at the maintenance, transformation and disruption of institutions. At the organisational level, institutional pluralism becomes an operationalisation of Selznickean 'critical experience' (Selznick, 1957, p. 38), calling for institutional leadership, where a range of alternative actions are possible and legitimate, tasks and goals are not defined, and, therefore, routine-based 
decision-making is unsuitable. We explore this issue by empirical examples of institutional pluralism and leadership in public administration.

The governance turn is observed in many Western and CEE countries (Denters, 2011). This simultaneous co-evolution of similar patterns of rule in public administration can be perceived as a process of institutional isomorphism (DiMaggio \& Powell, 1983; Rządca \& Strumińska-Kutra, 2016).

Isomorphic pressures are vehicles through which the disjunction between the values held by society and the behaviour of an organisation is erased. Changes in patterns of rule can be interpreted as a result of growing expectations for more responsive and inclusive public governance. Yet, public agencies still face expectations and pressures aligned with two other paradigms: PA privileging hierarchical logic and NPM imposing the quasi-market logic of effectiveness. The presence of multiple and often conflicting institutional orders, to which public organisations must adhere, complicates the process of isomorphism and legitimacy-building. Values pursued by public administrations, such as social justice and democracy, are understood differently in each of the paradigms. Within the hierarchical logic, public agencies are the final link in a chain of democratic representation. Here, executives enact the 'people's will', expressed in general elections. Network-based logic proposes building up societal and democratic consent through collaborative problem-solving (Ansell, 2011) and participatory forms of democracy. Market-based logic would build consent around the quality and costs of public services. Institutional pluralism poses a challenge to leadership in public administration. Bureaucracy or NPM may be impuissant when it comes to solving complex social problems, but this does not mean that we do not need them anymore (Ansell, 2011; Sørensen \& Torfing, 2015).

Institutional leadership is located where policy formation and organisation-building meet (Selznick, 1957, p. 37), and its role is to facilitate a dynamic adaptation to the values inherent in policies. In the face of the governance turn, public leaders are met with several challenges. First, to maintain or (re)create values and structures characteristic of each of the three paradigms. Second, to create and maintain meta-level, shared 
values that transcend but do not eliminate paradigmatic divisions (challenge 2, Besharov \& Khurana, 2015). The first requires work on integrity at the horizontal dimension, translating external expectations into the organisational structures and negotiating with bottom-up responses and managing tensions between symbolic (values, ideals) and technical (tools, procedures) (Besharov \& Khurana, 2015). ${ }^{2}$ The second is placed on a vertical axis, focusing on creating and maintaining 'a cap' that holds the parts together.

What has been largely omitted, even by Selznick himself, is that although specific types of institutions might be lacking, it does not mean that the arena of leaders' actions is empty of institutions. Concepts of institutional pluralism and ambiguity suggest that social spaces are never empty of institutions, rather, they can be perceived as institutional voids that result from conflict and contradiction among institutional bits and pieces from local political, community and religious spheres (Mair, Marti, \& Ventresca, 2012). Network-based coordination, typical for NPG, is introduced into a field already governed by diverse institutions. Even if collaborative approaches are not explicitly built into the organisational structures of public agencies, the institutional environment may deliver a more or less productive ground for establishing such ways of coordination. Horizontal ways of governing are not typical of the Polish institutional environment, which is the subject of empirical investigation here (see also Strumińska-Kutra, 2018). As a result, new collaborative approaches to public management are more easily interpreted according to the traditional hierarchical logic of PA, or to the relatively new but firmly embedded quasi-market logic of NPM. There is a lack of examples proving that horizontal coordination and partnerships not only confine the imagination on the realm of the possible but also reduce the resources necessary to initiate cooperation, most prominently social trust (Putnam, Leonardi, \& Nonetti, 1993). This adds a third challenge for an institutional leader because institutionalising a new approach means building new and changing old structures. Some values need to be reinterpreted or even removed in order to make a room for new structures.

\footnotetext{
2See also Askeland's chapter "Maintaining the good organization" in this volume.
} 
A fourth challenge is that the institutional leader herself is an institutionally embedded individual (Zietsma \& Lawrence, 2010) whose mindset and actions are influenced by institutions in a field. This sets her in the middle of an embedded agency paradox: How do those subject to the institutions in a field effect changes within them? Paying attention to leaders' institutional embeddedness in a cognitive and normative sense is an important supplementation of Selznick's concept. His original and current contributions portray the leader as a 'super individual' whose identity and perception are not affected by cognitive and normative aspects of institutions. Nevertheless, some of Selznick's remarks do connect to this problem of depicting leaders as individuals with the ability to transcend their own specialisation and who are conscious of their own weaknesses and potentialities (Selznick, 1957).

\section{The Institutional Embodiment of Purpose: Strategies for (Not) Building Integrity While (Not) Introducing Change}

In this section, we take a closer look at these challenges by utilising empirical illustrations ${ }^{3}$ of public administration leaders involved in processes towards more inclusive and collaborative governing patterns. In Poland, the beginning of these processes was marked by the decentralisation reform introduced in the late-1990s and the introduction of legislation on public participation and access to information at the beginning of the 2000s. The process accelerated in anticipation of EU accession in 2004. The leaders under analysis were acting upon public disputes understood as conflicts involving governmental entities and other stakeholders, such as individual citizens, business firms or organisations, over policy priorities, standards, or resources they hope to share' (Susskind, 2000, p. 130). Public disputes are instances where public administration

\footnotetext{
${ }^{3}$ Empirical investigation was conducted in years 2007-2017 and includes various types of data (interviews, archival sources, notes from observations) covering the time span between 1998 and 2017. Research was funded by the Polish Ministry of Science and Higher Education under the grant number: 2011/01/B/HS4/04935 and by Kozminski University.
} 
comes under direct pressure to implement ideals and regulations following an inclusive and collaborative logic of new policies. In the following examples, stakeholders demanded that public agencies enact participatory modes of governance, organise dialogue where all parties could express preferences and exchange knowledge in response to a given problem. They insisted that their values and knowledge be somehow included in solutions devised to address given policy dilemmas. Since the regulations and policies were new, organisational structures enabling their implementation either needed to be created or were in place but had hardly been practised. Institutional leadership was needed to create new structures and infuse them with vales (and meanings).

\section{Habitual and Projective Agency}

The introduction of new, collaborative logic and policy, accelerated by public disputes, questioned the goals and tools of public agencies and disrupted their routines. Following Selznick, we see disruption of routines as a disruption of logics commonly used to solve problems in the organisation (Selznick, 1957, p. 36). Dispute has the potential to create a 'critical experience' affecting the character of an organisation. This is the situation where distinct qualities of institutional leadership can be found. In order to create conditions 'that will make possible in the future what is excluded in the present' (Selznick 1957, p. 154), leaders perform institutional work (Lawrence \& Suddaby, 2006). They make critical decisions about how new regulations are to be understood and implemented in practice (Kraatz, 2009).

Selznick's leaders use projective agency, oriented at the formation and implementation of a new policy. Either they are foxes devising new programmes and techniques in cooperation with conservative elements, or lions, who secure innovations need for survival (Selznick, 1957, p. 112). Both roles require institutional innovation and entrepreneurship (DiMaggio, 1988; Maguire, Hardy, \& Lawrence, 2004; Zietsma \& Lawrence, 2010). Such leaders 'deal with current issues not for themselves alone but for their long run implications for the role and meaning of the group' (Selznick, 1957, p. 37). 
Yet, in practice, a failure to set goals, or only their superficial acceptation, is quite common. Below we shift attention to less explored institutional sources of leadership failures. We suggest that leaders may also use habitual agency that replicates existing patterns of thinking and acting.

Combining habitual and projective agency in analysing leaders' responses to pressures enables us to capture both how those subject to institutions in the field can implement changes and, more or less consciously, resist them. The latter in particular opens a venue for the exploration of cognitive aspects of institutional leadership since it addresses questions of institutional inertia (Hallet \& Ventresca, 2006; Kraatz \& Block, 2017; Mahoney \& Thelen, 2010). Following a previous analysis (Strumińska-Kutra, 2018), we combined two types of institutional work: practice work, understood as developing and legitimising practices, and identity work, or developing and legitimising roles and identities (Gawer \&Phillips, 2013; Svenningsson \& Alvesson, 2003; Zietsma $\&$ Lawrence, 2010) with habitual and projective agency. This analytical exercise enables the capturing of actions oriented to the creation of qualitatively new solutions (following a new logic) from actions oriented at proposing 'the same but in a new wrapping' (following the old logic) (Table 7.1).

Table 7.1 Institutional work around logic shifts

\begin{tabular}{lll}
\hline Habitual agency & Projective agency \\
\hline Identity work & $\begin{array}{l}\text { Developing and legitimizing } \\
\text { new identities within the } \\
\text { framework of the old } \\
\text { logic }\end{array}$ & $\begin{array}{l}\text { Striving to develop and } \\
\text { legitimize new roles and } \\
\text { identities within the } \\
\text { framework of the new } \\
\text { logic }\end{array}$ \\
Practice work & $\begin{array}{l}\text { Developing and legitimizing } \\
\text { new practices within the } \\
\text { framework of the old }\end{array}$ & $\begin{array}{l}\text { legitimize new practices } \\
\text { within the framework of } \\
\text { the new logic }\end{array}$ \\
\hline
\end{tabular}

Source Strumińska-Kutra, 2018 


\section{Empirical Illustrations}

We analyse leaders who faced isomorphic pressures for implementing participatory governance patterns. The pressures were accelerated by public disputes/conflict over policy priorities and standards. The first dispute concerned the closing of a school in a small rural community. The solution was to be formulated and the decision taken at the lowest level of public administration, which is the municipality. The mayor of the municipality enacted new regulations within the market and hierarchical narratives. Similar patterns of institutional inertia manifested in the case of a dispute over the construction of a flood prevention facility. Here, the director of an agency was responsible for organising public participation frames according to a hierarchical logic in which experts and bureaucrats were those who had the knowledge and made the decisions, while the public was the one who needed to be educated.

The two remaining disputes - over the location of a marketplace and of a wastewater treatment plant-took place in the same large city and the responsibility for planning and decision-making was split between the municipality and the province level. Two province-level leaders occupying the vice president position played a major role in the dispute over the marketplace. First, the vice president 'faked' participation to restore legitimacy and control-he ceremonially praised it without creating organisational structures to make it realistic. The second vice president (successor to the first) engaged in participatory practices and building narratives praising and justifying direct democracy and collaborative decision-making.

The analysis of dispute around the wastewater treatment plant brought the director of the Social Communication Department at the city administration to the forefront. He exploited opportunities created by external pressures in order to build organisational structures that facilitated access to public information, public participation and conflict mediation. ${ }^{4}$

The Mole: critical reflection on one's own specialism involves the ability to question one's own normative and cognitive patterns that guide thinking and acting on a problem. This ability is necessary to create

\footnotetext{
${ }^{4}$ For an extensive exploration of the cases, see Struminska-Kutra (2018).
} 
structures that go beyond static, routine-based adaptations. Without it, leaders continue business as usual by reinterpreting new expectations within routinised frames, not noticing new angles to the situation. For two of the leaders investigated in this analysis, the major obstacle in creating and practising new rules was that the new logic contradicted their belief system, particularly their convictions about professional identities and practices.

The mayor responsible for the decision regarding the closed school had no doubts about the roles of the parties involved in the dispute. She reconstructed them according to well-established institutional logics: citizens and non-public organisations are those who listen and vote or possibly deliver feedback regarding satisfaction with government decisions and services. When, at a council meeting, she was pressured for a public discussion on possible solutions to the school problem, she stated:

...once the resolution (about what to do) is adopted, I can officially consult people. I do not know what the Council's decision will be and I do not know what to ask the community. By reaching out to the community (after the resolution), we will know their opinion (...) We need to take a decision. I think this procedure is consistent with the letter of the law.

Identity work reinforces the work directed at developing and legitimising new practices, again within an old, habitual frame. Since the mayor could not imagine citizens contributing to the development of ideas, she advanced the solution herself, arguing for the need to vote over the proposed solution at council meetings. Having a resolution accepted by the council, she considered it ready for public consideration. The particular perception of the role played by citizens and officials also contributed to the creation of a bulletin that was to educate citizens on how public management processes work and why certain decisions, even if unpopular, need to be made. The same logic is visible in the eventually institutionalised practice of consulting citizens in quasi-surveys, asking whether they would accept or reject solutions developed by officials and councillors.

A similar mechanism of mutual reinforcement of practice and identity work was observed in the case of flood prevention facilities, where 
the perception of identities influenced practice work. The public agency director responsible for public consultation saw experts and officials as the owners of a superior knowledge. Thus, for him public consultations were about providing local communities with technical knowledge, allowing them to understand that the proposed solution was suitable: 'We have done it as usual: calmly, argumentatively, providing technical and professional information (...) We wanted to explain that we were doing the right thing' (interview, October 2013).

Importantly, each of the two leaders was motivated by a certain understanding of professional ethos, of doing what is right. They believed that their interpretation of participatory approaches was valuable.

The 'ostrich' responds to pressures for change by creating the appearance of compliance. This strategy was adopted by the city vice president, who was involved in the dispute over closing a local market. City authorities made the decision about the closure in order to use the area for building blocks of flats. The decision was made without consulting the local community, and it broke previous agreements with municipal authorities and merchants. When faced with protests, the vice president engaged in institutional work by developing ad hoc participatory practices. First, city authorities invited local community members to select among the projects of blocks. Since the project was the very reason for the protests, this did not calm the public. Then, two public meetings were organised. During the first meeting, the vice president and officials heard the opinions of the local community; during the second, held a year later, they presented a project modified in accordance with some of the requests. Protests escalated, and yet city authorities did not act on the problem for another two years. In the meantime, the vice president officially declared the authorities were going through 'the process of learning' to deal with public participation. Two years later, the vice president was approached by a group of researchers and urban activists, who proposed a mediation of the conflict. He agreed and appointed a representative for the city in the mediation process. Importantly, he neither equipped this person with special prerogatives nor gave his own active support. Mediation failed, and in the report announcing a closure, mediators explained: 
Despite detailed explanations of mediation principles and goals, Director $\mathrm{X}$ [appointed by the vice president] stated that she could not act as an actual representative of the city in the mediation process and that the procedure described by mediators was not defined in regulations governing the work of city authorities (...) A serious obstacle in the process of disseminating dialogue and consultation is the lack of unambiguous legal and procedural regulations which would justify and explain to citizens their access to civic dialogue.

The institutional work of the leader was not directed at re-defining the role of public administration during collaborative processes. It was instead focused on faking participatory approaches in order to restore legitimacy and keep control over decision-making, thereby avoiding critical decisions that could change how the organisation operated. His strategy was to wait out the conflict. The vice president did not risk any significant losses in terms of legitimacy, instead deciding to abstain from action. Merchants and local community representatives were just one of many groups involved in the many decision-making processes he had supervised over the years. Faking change was just enough to survive and remain in power.

Foxes: leaders who adopt the strategy of 'foxes' avoid confrontation with old structures by offering space where new practices can be implemented along with old practices, as well as a narrative of how new and old identities can be complementary and valuable at the same time. This approach was adopted by the Director of Social Communication Department (SCD), a unit created during a conflict over a wastewater treatment plant. Interestingly, this leader used the opportunity not to solve the conflict but to institutionalise the collaborative identities and practices in city administration structures. He skilfully built up the new departmental identity as being complementary to established identities. The following narrative from an interview illustrates the tactic:

They [officials from different departments] come to us when they face a conflict, because they are afraid and do not know how to deal with it (...) We need to combine the knowledge of experts representing different parties: those who use the city, those who manage it (officials), and experts in a given domain (for example, architects). Each of them 
thinks she knows best, but they know different things. Officials have a vast knowledge of procedures, they know what is allowed, and happens elsewhere. The experts know what can be done from the technical point of view. Citizens know, because they use the city every day. We facilitate the coordination of these perspectives; we make them respect each other to see the complementarity of their knowledge.

By building this integrative identity, he reduced internal tensions between the original organisational identity and new practices associated with the new logic (Svenningsson \& Alvesson, 2003). He effectively used social skills (Fligstein \& McAdam, 2012) to build social relationships, helping the organisation to cope with uncertainty and anxiety from the inevitable effects of institutional pluralism (Kraatz \& Block, 2017). Additionally, he combined the support of external environments, promoting participation with the internal support of the city president, who commissioned the creation of the department yet did not equipped it with financial resources. By actively reaching out to the external environment, he attracted professionals skilled in organising participation and financing from European Economic Area grants. He organised experimental public consultation processes in all municipalities of the city. Thus, he created opportunities for practice work, which is institutional work focused on establishing new patterns of action. He personally negotiated the financial and structural conditions of projects' implementation, which eventually resulted in setting up positions of public consultation officials in each municipality. In the following years, the director and his employees either established or supported the creation of new organisational structures, enabling public participatory action. Among others, there was the Public Consultation Platform, a register of all past and current consultation processes, and a city-level regulation defining public consultation and making it compulsory to announce each consultation process held by the city administration authorities on the Public Consultation Platform.

Lions: the goal of 'lions' is to secure the survival of innovations and to prevent them from drift or co-optation. They protect new, vulnerable 
structures from being taken over by opportunistic interest or reinterpretation that is inconsistent with the original 'spirit'. Hence, their strategies are more confrontational and may involve the deinstitutionalisation of organisational structures, contradicting new mission. The second vice president, also involved in the dispute over the marketplace, offers an example of this confrontational type. He entered the scene when the failing experiment with mediation was still ongoing. He refused, however, to follow in the former vice president's footsteps, instead taking back control of the process. He constructed a new, temporary structure, a working group, on the interface of city administration, municipality administration and external stakeholders' organisations. He established communication channels between these stakeholders and personally coordinated the process of designing solutions for the market. Importantly, although the new vice president shared the ideological orientation of collaborative approaches to governance, at the time, he had no experience in governing multi-stakeholder processes. What made the new vice president prone to learning new governance modes was a strong conviction that involving external stakeholders was the right thing to do, as well as social skills (Fligstein \& McAdam, 2012). The latter enabled him to create trust-based relationships with external constituents and organise collective action, combining actors from different levels and 'siloes' of public administration and external stakeholders.

Having a formal position of power, the new vice president was able to design new practices and make his subordinates follow them, even if it meant going against institutionalised methods and officials' convictions about their roles. Within new processes, the role of the members of the administration was to discuss different solutions with the community and merchants' representatives and to provide information about any procedural and material aspects of the situation. Importantly, employees trying to work according to the new collaborative logic received substantial support and could further learn and improve their practice. In this particular case, these were street-level bureaucrats, directly responsible for managing the market area, who were in touch with merchants on a daily basis. 
Along with introducing new practices, the new vice president performed institutional work by building narratives that justified new practices and identities and built organisational integrity around them. The most prominent example was the 'there-is-no-alternative' narrative about replacing the hierarchical approach to public management with a participatory approach. First, he claimed that such a replacement was a reality and second, a historical necessity, a sign that a public management structure was becoming 'civilised' (an original expression used by the vice president). When describing the hierarchical approach, he directly questioned the assumption of representative democracy in which citizens delegate power to politicians who then solve public problems through public administration. He framed this approach as obsolete and oldfashioned.

In 2006, you would hear such opinions everywhere. They would argue in favour of the iron rule of representative democracy and ask: if we should have direct participation and consultation, what are the councillors for? I hear such voices now, but no one dares say it out loud.

The major line of his argument was very different from the one used by the director of the SCD. Both believed in participatory approaches and promoted them, but the SCD director worked with a more inclusive, conciliatory strategy.

\section{Conclusions}

Institutions are broadly understood as 'the rules of the game' that direct and circumscribe organisational behaviour (Kraatz \& Block, 2017). Public agencies facing the three paradigms play in three games simultaneously. Historically speaking, they were made to play according to a hierarchical logic. Then, in the 1980s, institutional pressures for the adoption of market logic emerged. In the 1990s came the next shift, this time towards network-based, collaborative approaches to governance. Each of the logic sediments in organisational structures influences the way new organisational practices and identities are perceived (van de Bovenkamp, 
Stoopendaal, \& Bal, 2017). Whenever projective agency is used to create innovative solutions according to a new logic, there is a risk that old, deeper-rooted logic prevails, and what was supposed to be qualitatively different turns out to be an old thing in a new wrapping. Hence, the four challenges that institutional pluralism poses for an institutional leader in public administration are the challenges of maintaining and (re)creating structures that are characteristic of each paradigm; creating meta-level integrating values; deinstitutionalising some of the original structures; and transcending their own institutional embeddedness.

Our typology illustrates the responses to these challenges by tracing how leaders build organisational institutions that embody new goals and values while keeping organisational integrity. First, 'moles' and 'ostriches', use routinised patterns of thinking and acting (habitual agency) when creating new structures for collaboration. Yet, only the second can be accused of opportunism: the pursuit of immediate, shortterm political advantages (Selznick, 1957, p. 143). The 'ostrich' performs institutional work that is strategically focused on creating the appearance of compliance. Since he/she is faking change in response to pressures, her/his orientation is towards external not internal publics. The institutional work she performs addresses practices (visible from the outside) not identity work. 'Ostriches' only address the first challenge of structure creation, though in a selective and opportunistic way. The 'moles' are not opportunistic because, despite their habitual orientation, their work is values-based. She develops and legitimises new practices and identities within the old logic because that is the only logic she knows and believes in. This is also how she answers the challenge of integration, through the act of translation from new to old. She neutralises the tensions between logics by re-establishing old order.

'Foxes' and 'lions' use projective agency; infusing new forms and contents into organisational practices and identities. 'Foxes' build a structure while keeping the diverse paradigms in a creative tension and build an integrating narrative of complementarity and dialogue. For 'foxes', organisational integrity means wholeness rather than consistency, building structures that transcend but do not eliminate paradigmatic divisions (Besharov \& Khurana, 2015). In contrast, 'lions' aim for consistency. They use a confrontational strategy, which comes with the danger of 
organisational integration manifesting through the colonisation of the old paradigms by the new. Interestingly, this same danger is caused by the strategy of a 'mole', although projective agency provides the colonisation act with future-oriented not past-oriented content.

Only 'foxes' and 'lions' engage with the third challenge of deinstitutionalising some of the organisational patterns of thinking and acting. The strategy of the 'lion' evolves through confrontation. This poses the risk of subordinating one logic to the other and, hence, it is less fitting in the situation of institutional pluralism.

The fourth challenge of transcending one's own cognitive and normative embeddedness is indirectly addressed by the 'fox'. A 'fox' works at the interface of different logics by advancing a meta-level value of dialogue. By being exposed to various interpretations of the same values, ${ }^{5}$ she is more prone to engage in critical reflection upon her own understandings and actions. Moreover, by creating the structures for communication between perspectives, she builds a reflexive capacity into the organisation. In this sense, she provides an institutional leadership model that fits institutional pluralism best. It is also a model that best exploits conditions of pluralism to create opportunities for evolutionary for public good (Ansell, 2011).

\section{References}

Ansell, C. (2011). Pragmatist democracy: Evolutionary learning as public philosophy. Oxford: Oxford University Press.

Besharov, M. L., \& Khurana, R. (2015). Leading amidst competing technical and institutional demands: Revisiting Selznick's conception of leadership. In K. Matthew (Ed.), Institutions and ideals: Philip Selznick's legacy for organizational studies (pp. 53-88). Bingley: Emerald.

Bevir, M. (2011). Democratic governance: A genealogy. Local Government Studies, 37(1), 3-17. https://doi.org/10.1080/03003930.2011.539860.

Denters, B. (2011). Local governance. In M. Bevir (Ed.), The SAGE Handbook of Governance. London: Sage.

${ }^{5}$ For reflection about ambiguity of values, see Askeland, de Silva in this volume. 
DiMaggio, P. (1988). Interest and agency in institutional theory. In L. G. Zucker (Ed.), Institutional patterns and organizations: Culture and environment. Cambridge, MA: Ballinger.

DiMaggio, P., \& Powell, W. (1983). The iron cage revisited: Institutional isomorphism and collective rationality in organizational fields. American Sociological Review, 48, 147-160.

Fligstein, N., \& McAdam, D. (2012). A theory of fields. Oxford: Oxford University Press.

Gawer, A., \& Phillips, N. (2013). Institutional work as logics shift: The case of intel's transformation to platform leader. Organization Studies, 34(8), 10351071. https://doi.org/10.1177/0170840613492071.

Gilardi, F., \& Radaelli, C. M. (2012). Governance and learning. In D. LeviFaur (Ed.), The Oxford handbook of governance (pp. 155-168). Oxford: Oxford University Press.

Hallet, T., \& Ventresca, M. (2006). Inhabited institutions: Social interactions and organizational forms in Gouldner's "patterns of industrial bureaucracy". Theory and Society, 35(2), 213-236.

Kordasiewicz, A., \& Sadura, P. (2017). Clash of public administration paradigms in delegation of education and elderly care services in a postsocialist state (Poland). Public Management Review, 19(6), 785-801. https:// doi.org/10.1080/14719037.2016.1210903.

Kraatz, M. (2009). Leadership as institutional work: A bridge to the other side. In T. B. Lawrence, R. Suddaby, \& B. Leca (Eds.), Institutional work: Actors and agency in institutional studies of organizations (pp. 59-91). New York: Cambridge University Press.

Kraatz, M., \& Block, E. (2017). Institutional pluralism revisited. In R. Greenwood, C. Oliver, T. B. Lawrence, \& R. E. Meyer (Eds.), The SAGE handbook of organizational institutionalism (Vol. 2, pp. 635-662). London: Sage.

Lawrence, T. B., \& Suddaby, R. (2006). Institutions and institutional work. In S. R. Clegg, C. Hardy, T. B. Lawrence, \& W. Nord (Eds.), The SAGE handbook of organization studies (pp. 215-254). London: Sage.

Maguire, S., Hardy, C., \& Lawrence, T. B. (2004). Institutional entrepreneurship in emerging fields: HIV/AIDS treatment advocacy in Canada. Academy of Management Review, 47(5), 657-679.

Mahoney, J., \& Thelen, K. (2010). Explaining institutional change ambiguity, agency, and power. New York: Cambridge University Press.

Mair, J., Marti, M., \& Ventresca, M. (2012). Building inclusive markets in rural Bangladesh: How intermediaries work institutional voids. Academy of 
Management Journal, 55(4), 819-850. https://doi.org/10.5465/amj.2010. 0627.

Putnam, R., Leonardi, R., \& Nonetti, R. (1993). Making democracy work. Princeton, NJ: Princeton University Press.

Rządca, R., \& Strumińska-Kutra, M. (2016). Local governance and learning: In search of a conceptual framework. Local Government Studies, 42(6), 916937. https://doi.org/10.1080/03003930.2016.1223632.

Selznick, P. (1957). Leadership in administration: A sociological interpretation. Berkeley and Los Angeles, CA: University of California Press.

Sørensen, E., \& Torfing, J. (2015). Enhancing public innovation through collaboration, leadership and New Public Governance. In New frontiers in social innovation research (pp. 145-169). London: Palgrave Macmillan.

Strumińska-Kutra, M. (2018). Democratizing public management: Towards practice-based theory. New York: Palgrave Macmillan.

Susskind, L. (2000). Confessions of a public dispute mediator. Negotiation Journal, 16 (2), 129-132. https://doi.org/10.1111/nejo.2000.16.issue-2.

Svenningsson, S., \& Alvesson, M. (2003). Managing managerial identities: Organizational fragmentation, discourse and identity struggle. Human Relations, 56(10), 1163-1193.

Thornton, P. H., Ocasio, W., \& Lounsbury, M. (2012). The institutional logic perspective: A new approach to culture, structure and process. Oxford: Oxford University Press.

van de Bovenkamp, H. M., Stoopendaal, A., \& Bal, R. (2017). Working with layers: The governance and regulation of healthcare quality in an institutionally layered system. Public Policy and Administration, 32(1), 45-65. https:// doi.org/10.1177/0952076716652934.

Washington, M., Boal, K., \& Davis, J. (2008). Institutional leadership: Past, present, and future. In R. Suddaby, K. Sahlin-Andersson, C. Oliver, \& R. Greenwood (Eds.), The SAGE handbook of organizational institutionalism (pp. 719-733). London: Sage.

Zietsma, C., \& Lawrence, T. B. (2010). Institutional Work in the transformation of an organizational field: The interplay of boundary work and practice work. Administrative Science Quarterly, 55(2), 189-221. 
Open Access This chapter is licensed under the terms of the Creative Commons Attribution 4.0 International License (http://creativecommons.org/ licenses/by/4.0/), which permits use, sharing, adaptation, distribution and reproduction in any medium or format, as long as you give appropriate credit to the original author(s) and the source, provide a link to the Creative Commons license and indicate if changes were made.

The images or other third party material in this chapter are included in the chapter's Creative Commons license, unless indicated otherwise in a credit line to the material. If material is not included in the chapter's Creative Commons license and your intended use is not permitted by statutory regulation or exceeds the permitted use, you will need to obtain permission directly from the copyright holder.

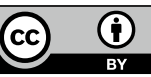

